\title{
Effects of chronic ethanol consumption on hepatic metabolism of aromatic and chlorinated hydrocarbons in rats
}

\author{
A SATO, T NAKAJIMA, AND Y KOYAMA \\ From the Department of Hygiene, Shinshu University Faculty of Medicine, Matsumoto, Japan
}

ABSTRACT The activities of liver drug-metabolising enzymes for 16 aromatic or chlorinated hydrocarbons were measured in male rats after a three-week daily intake of ethanol amounting to $30 \%$ of total energy intake. Although the ethanol feeding produced only a slight increase in the microsomal cytochrome P-450 content, it increased the in-vitro metabolism of most hydrocarbons threeto six-fold. That a major part of this enhanced activity disappeared after one-day withdrawal of ethanol suggests that recent intake of ethanol plays an important part in accelerating the metabolism of hydrocarbons. The enzyme activity enhanced by ethanol was found to be related with changes occurring not in the soluble but in the microsomal fractions. A metabolism study using toluene as a model substrate indicated that chronic ethanol consumption increases the in-vivo metabolism of this hydrocarbon in rats.

Although the activity of liver drug-metabolising enzymes $^{1-6}$ is increased by chronic alcohol administration, it is not known whether the consumption of ethanol can affect the susceptibility of workers to the toxic effects of pollutants in their working environment.

In the present study the effects of chronic ethanol feeding on liver metabolism of 16 aromatic or chlorinated hydrocarbons have been investigated in rats, and the results are discussed in relation to toxicity.

\section{Methods}

Male rats of Wistar strain were used throughout. They were kept in an air-conditioned room at 18$22^{\circ} \mathrm{C}$ in a daily 12-hour light cycle from 0600 to 1800. They were fed pellet food and water ad libitum until they reached a weight of $250 \mathrm{~g}$, when they were given $80 \mathrm{ml}(1 \mathrm{cal} / \mathrm{ml})$ of a liquid $\operatorname{diet}^{7}$ at 1600. The diet contained either ethanol (ethanoltreated rat) or isocaloric carbohydrate (control rat): on the first day of ethanol feeding, a diet containing $2 \%$ ethanol was given, and the concentration was increased by $1 \%$ a day to a final $5 \%$, equivalent to $30 \%$ of total calorie intake. After three weeks of

Received 19 July 1979

Accepted 22 January 1980 feeding they consumed the diet almost completely by midnight the same day.

\section{METABOLISM STUDY IN VITRO}

For the in-vitro enzyme assay rats were usually decapitated at 1000 . The liver was removed after exsanguination and a $10 \%(\mathrm{w} / \mathrm{v})$ crude homogenate was made with $1.15 \% \mathrm{KCl}-0.01 \mathrm{M}$ phosphate buffer, pH 7.4, in a Teflon-glass homogeniser. The homogenate was then centrifuged at $10000 \mathrm{~g}$ for $10 \mathrm{~min}$. One or $0.5 \mathrm{ml}$ of the $10000 \mathrm{~g}$ supernatant was normally used as the enzyme source for control or ethanol-treated rat, respectively. An aliquot of hydrocarbon was dissolved in distilled water, normally $5-10 \mu \mathrm{l} / 100 \mathrm{ml}$, and $0 \cdot 1 \mathrm{ml}$ of this solution was used as the substrate unless otherwise stated. The enzyme and substrate were incubated with a cofactor solution ( $2 \mathrm{ml}$ containing $5 \mu \mathrm{mol}$ of NADP, 10 $\mu \mathrm{mol}$ of glucose-6-phosphate, and $25 \mu \mathrm{mol}$ of $\mathrm{MgCl}_{2}$ in $0.1 \mathrm{M}$ phosphate buffer, $\mathrm{pH} \mathrm{7.4)}$ in an air-tight incubation vessel for $10 \mathrm{~min}$. The rate of enzymatic reaction was assessed by measuring the rate of substrate disappearance by gas chromatography as reported previously. ${ }^{8}$

Microsomal protein concentration was measured according to the method of Lowry et $\mathrm{al}^{9}$ as modified by Miller, ${ }^{10}$ and microsomal cytochrome P-450 content by the method of Omura and Sato. ${ }^{11}$ 
Table 1 Stimulation of drug-metabolising enzyme activities after chronic ethanol consumption

\begin{tabular}{|c|c|c|c|c|}
\hline \multirow[t]{2}{*}{ Hydrocarbons } & \multicolumn{3}{|c|}{ Metabolic rate, ${ }^{*}$ nmol/g liver/min } & \multirow[t]{2}{*}{$\mathrm{EtOH}(-) /$ control } \\
\hline & Control† & $\mathrm{EtOH}(+) \ddagger$ & $\mathrm{EtOH}(-) \S$ & \\
\hline Benzene & $13 \cdot 7 \pm 5 \cdot 4$ & $87 \cdot 5 \pm 13 \cdot 7$ & $15 \cdot 5 \pm 3 \cdot 3$ & $6 \cdot 4$ \\
\hline Toluene & $18 \cdot 1 \pm 4 \cdot 9$ & $88.5 \pm 2.6$ & $20 \cdot 5 \pm 5 \cdot 4$ & $4 \cdot 9$ \\
\hline$m$-Xylene & $21 \cdot 0 \pm 5 \cdot 5$ & $76.6 \pm 2.6$ & $22 \cdot 8 \pm 5 \cdot 1$ & $3 \cdot 6$ \\
\hline Styrene & $28 \cdot 5 \pm 4 \cdot 3$ & $90 \cdot 3 \pm 10 \cdot 1$ & $30.8 \pm 8 \cdot 3$ & $3 \cdot 2$ \\
\hline Dichloromethane & $28 \cdot 5 \pm 1 \cdot 5$ & $150.0 \pm 21.9$ & $36 \cdot 0 \pm 7 \cdot 2$ & $5 \cdot 3$ \\
\hline Chloroform & $19 \cdot 7 \pm 2 \cdot 6$ & $126.6 \pm 10 \cdot 5$ & $20 \cdot 2 \pm 1 \cdot 1$ & $6 \cdot 4$ \\
\hline Carbon tetrachloride & $1.9 \pm 0.2$ & $8 \cdot 3 \pm 1 \cdot 5$ & $1.7 \pm 0.3$ & $4 \cdot 4$ \\
\hline 1,1-Dichloroethane & $19 \cdot 1 \pm 3 \cdot 3$ & $120 \cdot 9 \pm 7 \cdot 5$ & $20.3 \pm 0.5$ & $6 \cdot 3$ \\
\hline 1,2-Dichloroethane & $23.6 \pm 1.1$ & $128.6 \pm 7.9$ & $22 \cdot 7 \pm 0.3$ & $5 \cdot 5$ \\
\hline 1,1,1-Trichloroethane & $0.5 \pm 0.2$ & $1.8 \pm 0.5$ & $0.6 \pm 0.3$ & $3 \cdot 6$ \\
\hline 1,1,2-Trichloroethane & $21.0 \pm 1.9$ & $117 \cdot 6 \pm 2 \cdot 1$ & $21 \cdot 5 \pm 1 \cdot 3$ & $5 \cdot 6$ \\
\hline $1,1,1,2$-Tetrachloroethane & $8 \cdot 1 \pm 2 \cdot 0$ & $29 \cdot 4 \pm 5 \cdot 5$ & $11 \cdot 0 \pm 3 \cdot 1$ & 3.6 \\
\hline $1,1,2,2$-Tetrachloroethane & $13 \cdot 3 \pm 0.6$ & $70.9 \pm 8.3$ & $16 \cdot 2 \pm 2 \cdot 5$ & $5 \cdot 3$ \\
\hline 1,1-Dichloroethylene & $31 \cdot 1 \pm 6.6$ & $100 \cdot 6 \pm 10 \cdot 8$ & $34 \cdot 1 \pm 4 \cdot 9$ & $3 \cdot 2$ \\
\hline Trichloroethylene & $18.9 \pm 7 \cdot 4$ & $105 \cdot 3 \pm 1 \cdot 5$ & $20 \cdot 1 \pm 5 \cdot 3$ & $5 \cdot 6$ \\
\hline Tetrachloroethylene & $0.5 \pm 0.3$ & $2.6 \pm 0.4$ & $0.5 \pm 0.4$ & $5 \cdot 2$ \\
\hline
\end{tabular}

* Mean \pm SD obtained from five rats.

$\leftarrow$ Rats fed control diet up to the day before death.

$\ddagger$ Rats fed ethanol-containing diet up to the day before death.

$\$$ Ethanol-treated rats fed control diet in place of ethanol-containing diet only on the day before death.

Data in the column "Control" have been reported previously. ${ }^{15}$

Table 2 Microsomal protein and cytochrome $P-450$ contents

\begin{tabular}{lll}
\hline & $\begin{array}{l}\text { Protein } \\
m g / g \text { liver }\end{array}$ & $\begin{array}{l}\text { Cytochrome P-450 } \\
\text { nmol/mg protein }\end{array}$ \\
\hline Control* $^{*}$ & $22 \cdot 7 \pm 2 \cdot 7$ & $0 \cdot 87 \pm 0 \cdot 12$ \\
EtOH $(+) \dagger$ & $24 \cdot 5 \pm 2 \cdot 0$ & $1 \cdot 22 \pm 0 \cdot 16$ \\
EtOH $(-) \ddagger$ & $21 \cdot 1 \pm 1 \cdot 5$ & $1 \cdot 00 \pm 0 \cdot 15$ \\
\hline
\end{tabular}

* Rats fed control diet up to the day before death.

+ Rats fed ethanol-containing diet up to the day before death.

$\ddagger$ Ethanol-treated rats fed control diet in place of ethanol-containing diet only on the day before death.

$\$$ Mean \pm SD obtained from five rats.

Significantly different from Control, $p<0.01$.

METABOLISM STUDY IN VIVO

For the in-vivo studies toluene was chosen as a model substrate. Eight rats, four with and four without ethanol feeding, were exposed to $500 \mathrm{ppm}$ of toluene for four hours (0800-1200) in a dynamic exposure chamber. ${ }^{12}$ After exposure the rats were kept in metabolism cages individually, and their urine was collected at preselected intervals for analysis for hippuric acid. Also at predetermined intervals, blood samples $(0.02 \mathrm{ml})$ were taken from a small cut made in the tail to determine the concentration of toluene. Urinary hippuric acid was measured by the method reported by Ogata and Sugihara, ${ }^{13}$ and the concentration of toluene in blood by a syringe-equilibration method. ${ }^{14}$ Pre-exposure urines of the rats were analysed for two consecutive days before exposure to toluene to measure the background level of hippuric acid excretion.

\section{Results}

EFFECTS OF CHRONIC ETHANOL CONSUMPTION ON THE IN-VITRO METABOLISM OF HYDROCARBONS

The metabolic rates of all the hydrocarbons studied were increased by chronic ethanol consumption (table 1). Microsomal cytochrome P-450 content was also increased significantly (table 2), but to a lesser extent. When the ethanol-containing diet was replaced by the ethanol-free diet on the day before death, the enhanced metabolic activity was reduced almost to the control level (table 1).

METABOLIC RATES OF TOLUENE AND TRICHLOROETHYLENE MEASURED BY INTERCHANGING MICROSOME AND SOLUBLE FRACTION BETWEEN ETHANOL-TREATED AND CONTROL RATS

In some experiments the $10000 \mathrm{~g}$ supernatant was centrifuged at $105000 \mathrm{~g}$ for $60 \mathrm{~min}$ and divided into soluble and microsomal fractions. The soluble fraction $[S]$ from an ethanol-treated rat was added to the microsome [M] from a control rat, and conversely, [S] from the control rat to [M] from the ethanol-treated rat. The metabolic rates of toluene and trichloroethylene were measured with these reconstituted $10000 \mathrm{~g}$ supernatants. The results in table 3 clearly indicate that the enhanced enzyme activity in ethanol-treated rats is related to the microsomal fraction and not to the soluble fraction. The underlying mechanism remains to be studied. 
Table 3 Metabolic rates of toluene and trichloroethylene measured by interchanging microsome $[M]$ and soluble fraction $[S]$ between control and ethanol-treated rats

\begin{tabular}{|c|c|c|}
\hline & \multicolumn{2}{|c|}{ Metabolic rate, ${ }^{*}$ nmol/g liver/min } \\
\hline & Toluene & Trichloroethylene \\
\hline \multirow{4}{*}{$\begin{array}{l}\text { [M] from control rat }+ \\
\text { [S] from control rat } \\
\text { [M] from control rat }+ \\
{[\mathrm{S}] \text { from ethanol-treated rat }} \\
\text { [M] from ethanol-treated rat }+ \\
\text { [S] from ethanol-treated rat } \\
\text { [M] from ethanol-treated rat }+ \\
\text { [S] from control rat }\end{array}$} & $16 \cdot 8 \pm 1 \cdot 1$ & $19 \cdot 4 \pm 2 \cdot 9$ \\
\hline & $16 \cdot 3 \pm 1 \cdot 5$ & $19 \cdot 2 \pm 2 \cdot 6$ \\
\hline & $76 \cdot 4 \pm 4 \cdot 8$ & $93 \cdot 5 \pm 5 \cdot 6$ \\
\hline & $79 \cdot 5 \pm 3 \cdot 3$ & $97 \cdot 7 \pm 4 \cdot 6$ \\
\hline
\end{tabular}

*Mean \pm SD of five measurements.

ETHANOL INHIBITION OF THE IN-VITRO METABOLISM OF TOLUENE AND

TRICHLOROETHYLENE

The effect of adding different concentrations of ethanol to the incubation mixture is shown in fig 1 . The results indicate that ethanol acts as a competitive inhibitor on the metabolism of these hydrocarbons. The inhibitor constant, $\mathrm{k}_{\mathrm{i}}$, of ethanol over toluene metabolism was $0.54 \mathrm{mmol} / \mathrm{l}$, and that over trichloroethylene $1.30 \mathrm{mmol} / \mathrm{l}$. Considering that the substrate concentrations were in the order of 3.25 to

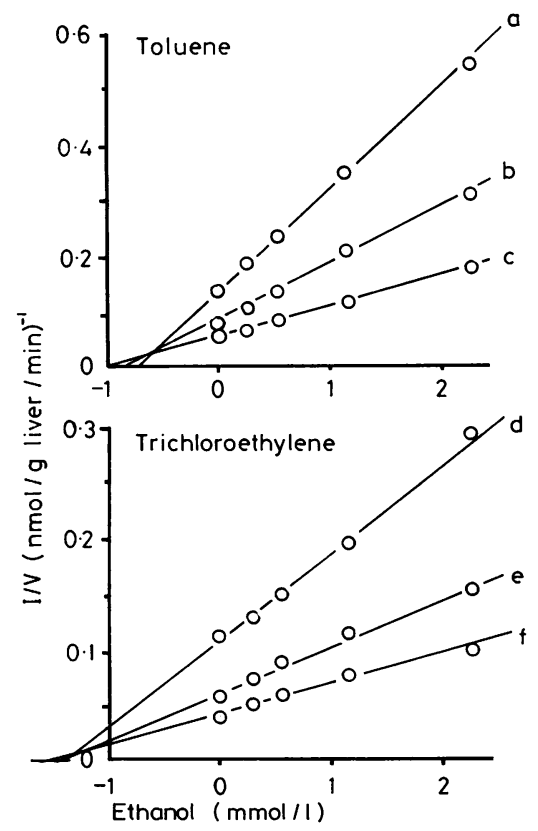

Fig 1 Reciprocal plots of metabolic rate (v) of toluene and trichloroethylene with addition of varying amounts

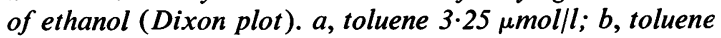
$4.82 \mu \mathrm{mol} / \mathrm{l} ; \mathrm{c}$, toluene $9.64 \mathrm{~mol} / \mathrm{l} ; \mathrm{d}$, trichloroethylene $3.92 \mu \mathrm{mol} / \mathrm{l} ; \mathrm{e}$, trichloroethylene $5.80 \mu \mathrm{mol} / \mathrm{l} ; \mathrm{f}$, trichloroethylene $11.60 \mu \mathrm{mol} / \mathrm{l}$.

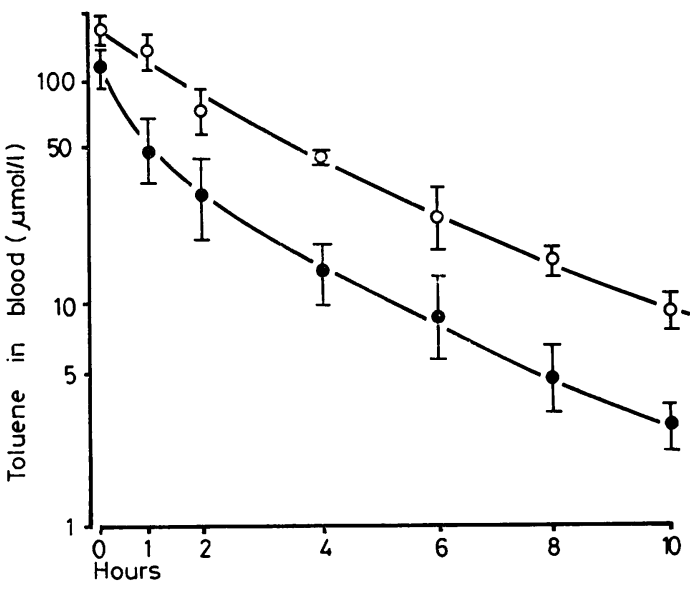

Fig. 2 Time-courses of toluene concentration in blood after a four-hour inhalation exposure to 500 ppm of toluene. Each point represents mean $\pm S D$ for four rats. $\bigcirc$ control rats; $\bigcirc$ ethanol-treated rats.

$11.60 \mu \mathrm{mol} / 1$, it can be said that ethanol is a relatively weak inhibitor of the metabolism of toluene and trichloroethylene. This suggests that ethanol may hardly inhibit the in-vivo metabolism of these hydrocarbons unless a considerable amount of ethanol coexists with them in the body.

ACCELERATION OF TOLUENE METABOLISM IN VIVO AFTER CHRONIC ETHANOL

CONSUMPTION

The decay curves of toluene in blood after a four-

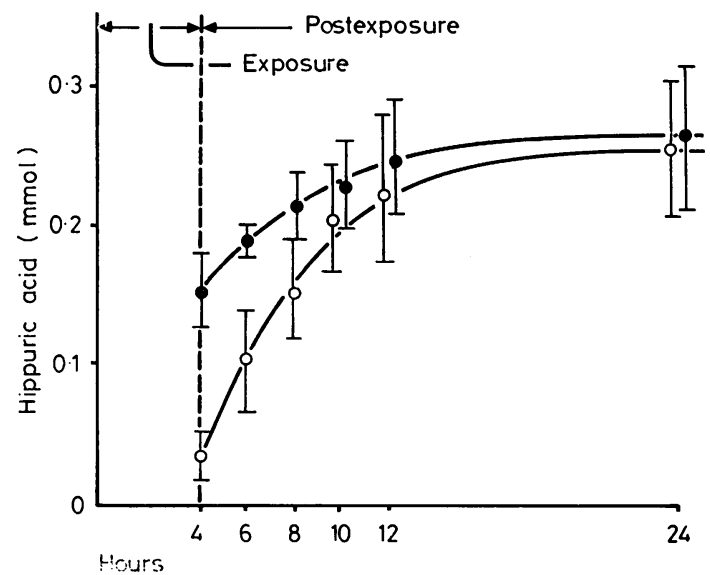

Fig 3 Cumulative amount of hippuric acid excreted in urine during and after a four-hour inhalation exposure to 500 ppm of toluene, naturally occurring background being eliminated. Each point represents mean $\pm S D$ for four rats. $\bigcirc$ control rats; - ethanol-treated rats. 
hour inhalation exposure at $500 \mathrm{ppm}$ of toluene are shown in fig 2. Figure 3 shows cumulative urinary hippuric acid excretion. Toluene disappeared more quickly from the blood of ethanol-treated rats than from the blood of control rats. In addition the ethanol-treated rats excreted much greater amounts of hippuric acid than the control rats during exposure. These findings indicate that chronic ethanol consumption accelerates the in-vivo metabolism of toluene in rats. In the ethanol-treated rats the blood ethanol concentration at the start of exposure $(0800)$ was $4-11 \mathrm{mmol} / \mathrm{l}$, although almost no ethanol was detected in the blood shortly after the cessation of exposure (1200). Possibly the ethanol present in the body during the early part of exposure may have exerted some inhibiting effects on the metabolism of toluene.

\section{Discussion}

Ethanol inhibits the metabolism of toluene and trichloroethylene competitively when added directly to the incubation system (fig 1). The metabolic rates of these hydrocarbons are increased in rats after chronic ethanol feeding (table 1). One-day withdrawal of ethanol, however, abolishes almost completely this effect of chronic ethanol consumption. This implies that the ethanol given one day before enzyme assay plays an important part in enhancing the liver drug-metabolising enzyme activities. In other words, a prolonged period of ethanol feeding may not always be a necessary condition for enzyme stimulation by ethanol. In fact, a single dose of ethanol, $5 \mathrm{~g} / \mathrm{kg}$, increased the metabolism of toluene and trichloroethylene both about two-fold 16 hours after its gastric intubation without causing any increase in the microsomal protein and cytochrome P-450 contents (table 4).

As pointed out by Ioannides and Parke, ${ }^{16}$ ethanol administered in vivo has both stimulating and inhibiting effects on drug-metabolising enzymes. When ethanol coexists in large amounts with foreign chemicals it suppresses their metabolism, stimulation occurring at a time when the ethanol has disappeared from the body. Selecting a proper period between last ethanol administration and death is, therefore, an essential factor in assessing the effects of ethanol consumption on the activity of drug-metabolising enzymes. In the present study the ethanol-containing liquid diet was consumed almost completely by midnight, 10 hours before death, when only small amounts of ethanol remained in the body.

The slight but significant increase in the cytochrome P-450 content in ethanol-treated rats (table 2) shows that chronic ethanol feeding induces the microsomal drug-metabolising enzymes-that is, causes de novo synthesis of the enzymes. The extent of the induction, however, is insufficient fully to account for the greatly enhanced enzyme activities. In addition, most of the enhanced activity disappears 24 hours after ethanol withdrawal. These findings may suggest that the effects of ethanol are qualitative rather than quantitative changes. It has been speculated that ethanol may act as a stimulator of the enzymes either by a modification of the membrane environment of the endoplasmic reticulum, by allosteric effects, or by the displacement of other endogenous or exogenous substrate already bound to the enzymes. ${ }^{16}$

Chronic ethanol feeding has been known to increase the susceptibility of rats to some toxic agents such as carbon tetrachloride. ${ }^{17}$ No exact mechanism for this potentiation of toxicity has been known. Hepatic injury from carbon tetrachloride is caused not by the toxicant itself but by its active intermediates produced in the course of its metabolism in the liver. ${ }^{18-20}$ Our present investigation suggests that the liver of rats fed ethanol metabolises carbon tetrachloride much more quickly than the liver of control rats. This may offer a possible explanation to the reported increase in susceptibility of ethanol-treated rats to the hepatotoxicity of carbon tetrachloride. It is possible to deduce by analogy with carbon tetrachloride that chronic ethanol consumption may also increase the susceptibility of rats to other hepatotoxic hydrocarbons which are metabolised to a more toxic form such as chloroform ${ }^{21}$ and 1,1-dichloroethylene. ${ }^{22} 23$

Table 4 Effects of a single dose of ethanol on the in-vitro metabolism of toluene and trichloroethylene

\begin{tabular}{|c|c|c|c|c|}
\hline & \multirow{2}{*}{$\begin{array}{l}\text { Microsomal protein* } \\
\mathrm{mg} / \mathrm{g} \text { liver }\end{array}$} & \multirow{2}{*}{$\begin{array}{l}\text { Cytochrome } P-450^{*} \\
\text { nmol/mg protein }\end{array}$} & \multicolumn{2}{|c|}{ Metabolic rate, ${ }^{*}$ nmol/g liver/min } \\
\hline & & & Toluene & Trichloroethylene \\
\hline $\begin{array}{l}\text { Ethanol-dosed rats } \\
\text { Controls }\end{array}$ & $\begin{array}{l}23 \cdot 7 \pm 1 \cdot 2 \\
25 \cdot 0 \pm 0.9\end{array}$ & $\begin{array}{l}0.85 \pm 0.20 \\
0.83 \pm 0.17\end{array}$ & $\begin{array}{l}45 \cdot 8 \pm 11 \cdot 4 \\
25 \cdot 7 \pm 3 \cdot 0\end{array}$ & $\begin{array}{l}63 \cdot 9 \pm 15 \cdot 1 \\
30 \cdot 4 \pm 4 \cdot 2\end{array}$ \\
\hline
\end{tabular}

Male Wistar rats maintained on commercial pellet food were used. A single dose of ethanol, $5 \mathrm{~g} / \mathrm{kg}$ as a $50 \%$ aqueous solution, was given to one group of rats at 1600 (ethanol-dosed rats), and an isocaloric glucose solution was given to another (controls). They were killed 16 hours after treatment, that is, at $\mathbf{0 8 0 0}$ on the next day. Between treatment and death, they were deprived of food with free access to drinking water.

* Mean $\pm S D$ for four rats. 


\section{References}

${ }^{1}$ Rubin E, Lieber CS. Hepatic microsomal enzymes in man and in rat: induction and inhibition by ethanol. Science 1968;162:690-1.

${ }^{2}$ Ariyoshi T, Takabatake E, Remmer H. Drug metabolism in ethanol induced fatty liver. Life Sci 1970;9:361-9.

${ }^{3}$ Misra PS, Lefevre A, Ishii H, Rubin E, Lieber CS. Increase of ethanol, meprobamate and pentobarbital metabolism after chronic ethanol administration in man and in rats. Am J Med 1971;51:346-51.

4 Ishii H, Joly J-G, Lieber CS. Effect of ethanol on the amount and enzyme activities of hepatic rough and smooth microsomal membranes. Biochim Biophys Acta $1973 ; 291: 411-20$.

${ }^{5}$ Liu S-J, Ramsey RK, Fallon HJ. Effects of ethanol on hepatic microsomal drug-metabolizing enzymes in the rat. Biochem Pharmacol 1975;24:369-78.

- Khanna JM, Kalant H, Yee Y, Chung S, Siemens AJ. Effect of chronic ethanol treatment on metabolism of drugs in vitro and in vivo. Biochem Pharmacol 1976;25: 329-35.

7 DeCarli LM, Lieber CS. Fatty liver in the rat after prolonged intake of ethanol with a nutritionally adequate liquid diet. $J$ Nutr 1967;91:331-6.

${ }^{8}$ Sato A, Nakajima T. A vial-equilibration method to evaluate the drug-metabolizing enzyme activity for volatile hydrocarbons. Toxicol Appl Pharmacol 1979;47: 41-6.

${ }^{9}$ Lowry OH, Rosebrough NJ, Farr AL, Randall RJ. Protein measurement with the folin phenol reagent. $J$ Biol Chem 1951;193:265-75.

10 Miller GL. Protein determination for large numbers of samples. Anal Chem 1959;31:964.

11 Omura T, Sato R. The carbon monoxide-binding pigment of liver microsomes. 1 Evidence for its hemoprotein nature. J Biol Chem 1964;239:2370-8.

12 Sato A, Nakajima T, Fujiwara Y, Murayama N. Kinetic studies on sex difference in susceptibility to chronic benzene intoxication-with special reference to body fat content. Br J Ind Med 1975;32:321-8.

13 Ogata M, Sugihara R. An improved method of direct colorimetric determination of hippuric acid in urine. Jap J Ind Health 1976;18:40-1. (In Japanese.)

14 Sato A, Nakajima T, Fujiwara Y. Determination of benzene and toluene in blood by means of a syringeequilibration method using a small amount of blood. $\mathrm{Br}$ $J$ Ind Med 1975;32:210-4.

${ }^{15}$ Nakajima T, Sato A. Enhanced activity of liver drugmetabolizing enzymes for aromatic and chlorinated hydrocarbons following food deprivation. Toxicol Appl Pharmacol 1979:50:549-56.

${ }^{16}$ Ioannides C, Parke DV. The effect of ethanol administration on drug oxidations and possible mechanism of ethanol-barbiturate interactions. Biochem Soc Trans 1973;1:716-20.

17 Hasumura Y, Teschke R, Lieber CS. Increased carbon tetrachloride hepatotoxicity, and its mechanism, after chronic ethanol consumption. Gastroenterology 1974; 66:415-22.

18 Butler TC. Reduction of carbon tetrachloride in vivo and reduction of carbon tetrachloride and chloroform in vitro by tissues and tissue homogenates. J Pharmacol Exp Ther 1961;134:311-9.

19 McLean AEM, McLean EK. The effect of diet and 1,1,1trichloro-2,2-bis-( $p$-chlorophenyl) ethane (DDT) on microsomal hydroxylating enzymes and on sensitivity of rats to carbon tetrachloride poisoning. Biochem $J 1966$; 100:564-71.

${ }^{20}$ Slater TF. Necrogenic action of carbon tetrachloride in the rat. A speculative mechanism based on activation. Nature 1966;209:36-40.

${ }^{21}$ Ilett KF, Reid WD, Sipes IG, Krishna G. Chloroform toxicity in mice: correlation of renal and hepatic necrosis with covalent binding of metabolites to tissue macromolecules. Exp Mol Pathol 1973;19:215-29.

22 Jaeger RJ, Conolly RB, Murphy SD. Effect of $18 \mathrm{hr}$ fast and glutathione depletion of 1,1-dichloroethyleneinduced hepatotoxicity and lethality in rats. Exp Mol Path 1974;20:187-98.

${ }^{23}$ Bartsch H, Malaveille C, Montesano R, Tomatis L. Tissue-mediated mutagenicity of vinylidene chloride and 2-chlorobutadiene in Salmonella typhimurium. Nature 1955;255:641-3. 